\title{
Contact Lens and Keratitis
}

\author{
Mazin S Salman* \\ PhD Medical Microbiology, Ministry of Education, Iraq \\ *Corresponding Author: Mazin S Salman, PhD Medical Microbiology, Ministry \\ of Education, Iraq.
}

Received: February 17, 2020

Published: March 03, 2020

(c) All rights are reserved by Mazin S Salman.
Nowadays lenses are used to give eyes an attractive color. In some cases, the use of these lenses carries many risks, including infection with Keratitis [1]. Pseudomonas aeruginosa is mostly causative pathogen. P. aeruginosa return to the Pseudomonadaceae family, as this family includes as well as the genus Pseudomonas and the genus Xanthomonas. The genus Pseudomonas includes in addition to $P$. aeruginosa two other pathogens of humans which are P. mallei, and P. pseudomallei. These bacteria have great adaptability in environments not suitable for the growth of microorganisms, which may be virtually non-nutrient, as they can grow even in water that contains a very small amount of nutrients such as tap water, their growth has been observed in distilled water, which indicates that the requirements Food for these bacteria is very limited. This ability to spread due to bacteria owning several enzymes that work with genetic regulation. Bacteria has the largest sequence of nitrogenous base pairs, as P. aeruginosa has more than 6 million base pairs and approximately 5,500 genes, while $E$. coli has 4.6 million pairs Base and approximately 4,200 genes [2]. This large number of genes indicates that bacteria have the ability to adapt in many environments, and it has also been observed that they have the ability to show phenotypic variation, which leads to the division of the bacterial community into groups that express different surface compounds. With this strategy, the bacteria can escape from the host's immune defenses $[3,4]$. Bacterial keratitis is one of the most dangerous lesions in pathology due to the frequency of its occurrence and the complications resulting from it. One study indicates that there is one eye that loses daily in the world due to the use of contact lenses [5]. P. aeruginosa is one of the most important factors that cause keratitis. Microbial lead to ulceration of the cornea, which, if not treated, can lead to vision loss. $P$. $a e$ ruginosa is a pathogen that has virulence factors and causes serious eye injuries. Corneal puncture can occur in less than 24 hours during its infection with $P$. aeruginosa. Another complication is corneal opacity that leads to visual acuity. These complications are eliminated only if a new patch is implanted to the cornea. The inflammation of the cornea caused by P. aeruginosa is characterized by the infiltration of the inflammatory cells with rapid tissue damage and that this injury can lead to corneal perforation, intraocular injuries, iris damage, lens opacity, and finally it causes endophthal- mitis. Protease enzymes work together to break down the base materials of the cornea and other supporting structures and constituents of fibrin and Elastin, as well as that cytotoxin and hemolysins also contribute to the sweep process. Most ideal antiseptics are ineffective in eradicating bacteria, and in general the bacteria are resistant to many of the commonly used antibiotics, and forms of resistance develop in these bacteria. The infection with $P$ aeruginosa, which causes keratitis, is the most difficult to treat compared to other infections caused by other microorganisms.

\section{Bibliography}

1. Stapleton F and Carnt N. "Contact lens-related microbial keratitis: how have epidemiology and genetics helped us with pathogenesis and prophylaxis". Eye 26 (2012): 185-193.

2. Kung VL., et al. "The Accessory Genome of Pseudomonas aeruginosa". Microbiology and Molecular Biology Reviews 74 (2010): 621-641.

3. Mocali S., et al. "Ecology of cold environments: new insights of bacterial metabolic adaptation through an integrated genomic-phenomic approach". Scientific Reports 7 (2017): 839.

4. Stubbendieck RM., et al. "Bacterial Communities: Interactions to Scale". Frontiers in Microbiology 7 (2016).

5. Eltis M. "Contact-lens-related microbial keratitis: case report and review". Journal of Optometry 4 (2011): 122-127.

\section{Assets from publication with us}

- Prompt Acknowledgement after receiving the article

- Thorough Double blinded peer review

- Rapid Publication

- Issue of Publication Certificate

- High visibility of your Published work

Website: https://www.actascientific.com/

Submit Article: https://www.actascientific.com/submission.php Email us: editor@actascientific.com

Contact us: +919182824667 